\title{
EFEKTIVITAS HUKUMAN UNTUK MENINGKATKAN DISIPLIN SANTRI PUTRI MADRASAH ALIYAH
}

\section{THE EFFECTIVENESS OF DISCIPLINARY PENALTIES TO IMPROVE WOMEN STUDENTS ISLAMIC SENIOR HIGH SCHOOL}

\author{
EW Rahayu' ${ }^{1 a}$ dan M Ichsan ${ }^{1}$ \\ 1 Program Studi Manajemen Pendidikan Islam, Fakultas Keguruan dan Ilmu Pendidikan, \\ Universitas Djuanda Bogor, Jl. Tol Ciawi No. 1 Kotak Pos 35 Ciawi Bogor 16720 \\ a Korespondensi: Euis Widiawati Rahayu, Email: euiswr84@gmail.com \\ (Diterima: 13-12-2016; Ditelaah: 15-12-2016; Disetujui: 28-03-2017)
}

\begin{abstract}
This study aims to determine: 1) the punishment according to the theory of education, 2) discipline in Pesantren Modern Daarul 'Uluum Lido, 3) the effectiveness of penalties to enforce discipline female student's madrasah Aliyah Daarul 'uluum lido. Discussion of this paper is based on field research aims to obtain data or information, whether in the form of interviews and documents related to the variable boarding research done by jumping directly spaciousness in order to obtain valid data. The collected data is compiled and then newly analyzed. This analysis is useful for writers in an effort to dig further on the issue of the effectiveness of punishment in disciplining students. The results showed that (1) Punishment meted out to children have the condition and kind, because it is not a good punishment that is cornered but sensitize and educate. Do not take action against a child by force, but with the subtlety of their heart, and be motivated and persuasion. (2) In this study addressed several disciplines are applied at the school, among other things: the discipline of time, learning discipline, and discipline to behave. (3) The penalty is the consequence will be obtained for violators of discipline in boarding. Penalties were indeed shown to be effective in making students disciplined, when it refers to the sentencing guidelines in giving punishment and boarding policy. But sometimes the punishment will have an impact on students' feelings of hatred when physical harm and does not contain educational elements.
\end{abstract}

Keywords: discipline of students, effectiveness of punishment.

\begin{abstract}
ABSTRAK
Penelitian ini bertujuan untuk mengetahui: 1) pemberian hukuman menurut teori pendidikan, 2) disiplin di Pesantren Modern Daarul 'Uluum Lido, 3) efektivitas hukuman untuk meningkatkan disiplin santri putri madrasah aliyah daarul 'uluum lido.Pembahasan skripsi ini berdasarkan penelitian lapangan (field research) yang bertujuan untuk mendapatkan data atau informasi, baik berupa hasil wawancara dan dokumen pesantren yang berkaitan dengan variabel penelitian yang dilakukan dengan cara terjun langsung kelapangan demi memperoleh data yang valid. Data yang terkumpul disusun dan kemudian baru dianalisis. Analisa ini berguna bagi penulis sebagai upaya penggalian lebih lanjut mengenai masalah efektivitas hukuman dalam mendisiplinkan santri. Hasil penelitian menunjukan bahwa (1) Hukuman yang dijatuhkan kepada anak mempunyai syarat dan macamnya, karena hukuman yang baik itu bukanlah yang bersifat memojokkan tetapi menyadarkan dan mendidik. Jangan menindak anak dengan kekerasan, tetapi dengan kehalusan hati, lalu diberi motivasi dan persuasi. (2) Dalam penelitian ini dibahas beberapa disiplin yang diterapkan di pesantren tersebut, yaitu antara lain: disiplin waktu, disiplin belajar, dan disiplin bertingkah laku. (3) hukuman
\end{abstract}


merupakan konsekuensi yang akan didapatkan bagi pelanggar disiplin di Pesantren. Hukuman yang diberikan memang terbukti efektif dalam membuat santri berdisiplin, apabila pemberian hukuman tersebut mengacu kepada pedoman dalam memberikan hukuman dan kebijakan pesantren. Tetapi kadang hukuman akan berdampak pada perasaan benci anak didik apabila menyakiti fisik dan tidak mengandung unsur edukatif.

Kata kunci: disiplin santri, efektivitas hukuman.

Rahayu EW dan M Ichsan. 2017. Efektivitas hukuman untuk meningkatkan disiplin santri putri Madrasah Aliyah. Tadbir Muwahhid 1(1): 13-31.

\section{PENDAHULUAN}

Dalam dunia pendidikan istilah punishment atau hukuman. Pada umumnya hukuman terjadi karena tindakan kejahatan, seperti membunuh, mencuri, penganiayaan dan lain-lain. Berbeda dengan dunia pendidikan, hukuman diberikan kepada santri yang melanggar norma dan aturan yang telah ditetapkan di lembaga pendidikan. Hukuman diterapkan agar peserta didik jera atau sebagai pelajaran supaya santri tersebut tidak melakukan sesuatu yang buruk, hal ini ditakutkan akan menjadi kebiasaan yang nantinya dapat merusak masa depannya. Karena hukuman adalah suatu alat pendidikan yang juga diperlukan dalam pendidikan (Baharudin 2015). Sebab, hukuman merupakan salah satu alat dari sekian banyak alat lainnya yang digunakan untuk meningkatkan perilaku yang diinginkan dan mengurangi perilaku yang tidak diinginkan (Gaza 2012 ).

Secara psikologi hukuman dapat dipandang sebagai sumber motivasi dalam keseluruhan perilaku manusia. Misalnya, seorang peserta didik menghindari untuk tidak mencontek dalam ujian karena tahu bahwa perbuatan menyontek tersebut adalah perbuatan yang tidak baik dan dapat dikenakan hukuman antara lain tidak lulus. Dari sudut pandang pendidikan hukuman merupakan suatu alat pendidikan baik didalam sekolah maupun di luar sekolah yaitu sebagai alat dalam proses upaya mengembangkan kepribadian peserta didik (Surya 2003).

Pada lembaga pendidikan formal maupun nonformal terdapat hukuman yang telah ditetapkan, maka di dalamnya pun terdapat aturan-aturan yang harus dilaksanakan. Salah satu fungsi hukuman yaitu untuk menambah kedisiplinan. Seperti menurut Supardi dan Aqila dalam bukunya ide-ide Kreatif Mendidik Anak, bahwa sebuah peraturan sebagus apapun itu pasti dibutuhkan kedisiplinan (Supardi 2010).

Pelatihan disiplin diharapkan dapat menumbuhkan kendali diri, karakter atau keteraturan, dan efisiensi. Jadi secara singkat dapat disimpulkan bahwa disiplin berhubungan dengan pengendalian diri supaya dapat menbedakan mana yang benar dan mana yang salah sehingga dalam jangka panjang diharapkan bisa menumbuhkan perilaku bertanggung jawab.

Pondok pesantren adalah salah satu lembaga pendidikan yang bergerak dalam bidang pendidikan yang berbasis agama. Pendidikan yang diselenggarakan tidak hanya sekedar proses mentransfer ilmu pengetahuan dan keahlian, tetapi sekaligus mentransfer nilai-nilai moral dan keyakinan dari generasi sebelumnya kegenerasi berikutnya. Pesantren juga sekaligus lembaga sosial dan lembaga keagamaan yang pengasuhnya juga menjadi pimpinan umat yang menjadi rujukan legitimasi terhadap warganya (Maunah 2010). 
Hukuman yang diterapkan di Pesantren Modern Daarul 'Uluum Lido bertujuan untuk mendidik dan mendisiplinkan santri agar dapat merubah perilaku atau kebiasaan buruk supaya menjadi yang lebih baik. Sedangkan beratnya hukuman yang dijatuhkan disesuaikan dengan besarnya kesalahan atau pelanggaran yang telah diperbuat. Hal ini merupakan tantangan karena begitu sulitnya mendisiplinkan santri saat berada di dalam Pesantren. Peneliti dalam hal ini mencoba meneliti bagaimana hukuman berupa Iqob dan Denda ini dapat meningkatkan kedisiplinan santri khususnya santri putri di pesantren.

\section{MATERI DAN METODE}

\section{Materi}

Menurut Kamus Besar Bahasa Indonesia, kata efektif mempunyai arti efek, pengaruh, akibat atau dapat membawa hasil. Efektivitas menekankan pada hasil yang dicapai, sedangkan efisiensi lebih melihat pada bagaimana cara mencapai hasil yang dicapai itu dengan membandingkan antara input dan outputnya (Siagaan 2001). Efektivitas suatu program dapat dilihat dari aspek-aspek antara lain: (1) Aspek tugas atau fungsi, yaitu lembaga dikatakan efektivitas jika melaksanakan tugas atau fungsinya, begitu juga suatu program pembelajaran akan efektif jika tugas dan fungsinya dapat dilaksanakan dengan baik dan peserta didik belajar dengan baik; (2) Aspek rencana atau program, yang dimaksud dengan rencana atau program disini adalah rencana pembelajaran yang terprogram, jika seluruh rencana dapat dilaksanakan maka rencana atau progarm dikatakan efektif; (3) Aspek ketentuan dan peraturan, efektivitas suatu program juga dapat dilihat dari berfungsi atau tidaknya aturan yang telah dibuat dalam rangka menjaga berlangsungnya proses kegiatannya. Aspek ini mencakup aturanaturan baik yang berhubungan dengan guru maupun yang berhubungan dengan peserta didik, jika aturan ini dilaksanakan dengan baik berarti ketentuan atau aturan telah berlaku secara efektif; dan (4) Aspek tujuan atau kondisi ideal, suatu program kegiatan dikatakan efektif dari sudut hasil jika tujuan atau kondisi ideal program tersebut dapat dicapai. Penilaian aspek ini dapat dilihat dari prestasi yang dicapai oleh peserta didik (Muasaroh 2010).

Istilah punishment atau hukuman. Pada umumnya hukuman terjadi karena tindakan kejahatan, seperti membunuh, mencuri, penganiayaan dan lain-lain. Berbeda dengan dunia pendidikan, hukuman diberikan kepada santri yang melanggar norma dan aturan yang telah ditetapkan di lembaga pendidikan. Hukuman diterapkan agar peserta didik jera atau sebagai pelajaran supaya santri tersebut tidak melakukan sesuatu yang buruk, hal ini ditakutkan akan menjadi kebiasaan yang nantinya dapat merusak masa depannya. Karena hukuman adalah suatu alat pendidikan yang juga diperlukan dalam pendidikan (Baharudin 2015). Sebab, hukuman merupakan salah satu alat dari sekian banyak alat lainnya yang digunakan untuk meningkatkan perilaku yang diinginkan dan mengurangi perilaku yang tidak diinginkan.

\section{Metode}

\section{Tempat dan Waktu Penelitian}

Penelitian ini dilakukan di Pesantren Modern Daarul 'Uluum Lido Bogor tepatnya berlokasi di kaki gunung salak yang beralamatkan di Jl. Mayjen HR. Edi Sukma KM. 22 Kampung Muara Desa Ciburuy Kecamatan Cigombong Kabupaten Bogor. 


\section{Metode dan Prosedur Penelitian}

Penelitian ini bentuknya adalah penelitian kualitatif, karena data-data akan dipaparkan secara analisis deskriptif. Sedangkan penelitian kualitatif itu sendiri menurut Bogdan dan Taylor seperti dikutip Moleong, adalah Prosedur penelitian yang menghasilkan data deskriptif berupa katakata tertulis atau lisan dari orang-orang dan pelaku yang diamati (Moleong 2016).

\section{Data dan Sumber Data}

\section{Data Primer}

Data primer yaitu data yang langsung diambil oleh orang yang berkepentingan atau yang memakai data tersebut. Data yang diperoleh melalui sumber informasi dengan cara observasi (pengamatan) dan wawancara. Dalam penelitian ini data primer diambil oleh pernyataan Bagian keamanan dan santri yang pernah/sering terkena hukuman, baik hukuman ta'zir atau 'iqab.

\section{Data skunder}

Data skunder yaitu data yang tidak secara langsung diperoleh oleh yang berkepentingan atau yang memakai data tersebut. Data skunder peneliti didapatkan dari data dokumentasi atau laporan yang tersimpan sebagai arsip di Pesantren.

\section{Teknik Pengumpulan Data}

Teknik pengumpulan data merupakan salah satu hal yang sangat penting bagi sebuah penelitian sehingga data yang diperoleh benar-benar sesuai dengan judul yang ditentukan. Seperti yang diungkapan oleh Prof. Dr. Sugiyono bahwa dari segi cara atau teknik pengumpulan data, maka teknik pengumpulan data dapat dilakukan dengan observasi (pengamatan), interview (wawancara), dan dokumentasi (Sugiyono 2016).

\section{Teknik Analisis Data}

Menurut Sugiyono, analisis data kualitatif adalah proses mencari dan menyusun secara sistematis data yang diperoleh dari hasil pengamatan (observasi), wawancara, catatan lapangan, dan studi dokumentasi, dengn cara mengorganisasikan data ke sintesis, menyusun ke dalam pola, memilih mana yang penting, dan mana yang akan dipelajari, dan membuat kesimpulan sehingga mudah dipahami oleh diri sendiri maupun orang lain (Sugiyono 2016).

Untuk mnganalisa data yang telah diperoleh peneliti, maka menggunakan analisis data model Miles \& Huberman, dengan tahapan sebagai berikut: 1) Reduksi data (data reduction), 2) display/penyajian data, dan 3) mengambil kesimpulan lalu diverifikasi.

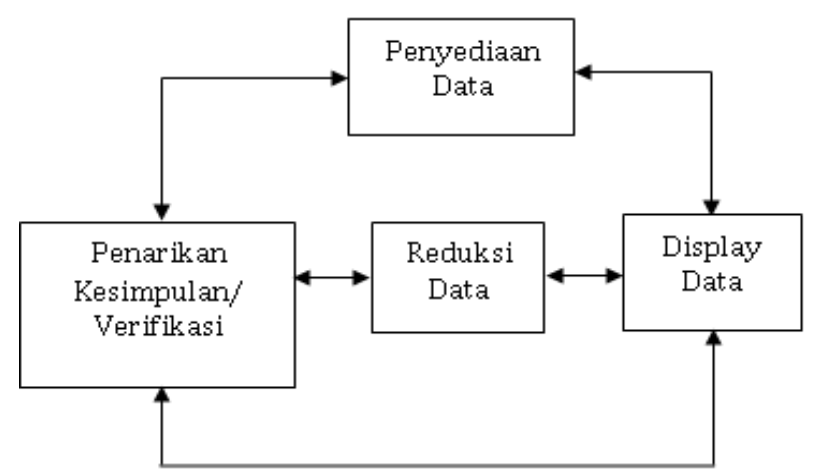

Gambar 1 Prosedur analisis data

\section{Pemeriksaan Keabsahan Data}

Keabsahan data merupakan konsep penting yang diperbaharui dari konsep kesahihan (validitas) dan keandalan (reliabilitas) menurut versi "positivisme" dan disesuaikan dengan tuntutan pengetahuan, kriteria, dan paradigmanya sendiri (Moleong 2016).

Pemeriksaan keabsahan data dalam penelitian kualitatif meliputi uji kepercayaan (kredibilitas), keteralihan (transferabilitas), kebergantungan (dependabilitas), dan kepastian (komfirmabilitas). Masing-masing kriteria tersebut menggunakan teknik pemeriksaan sendiri-sendiri. 


\section{HASIL DAN PEMBAHASAN}

\section{Hasil}

Proses pengumpulan data dilakukan dengan kegiatan wawancara, ini dilakukan untuk memperoleh data dalam penelitian kualitatif dan dilakukan di dalam lingkungan pesantren Daarul 'Uluum Lido seperti pada Tabel 1.
Untuk mengetahui hasil dari penelitian ini, berkenaan dengan efektivitas hukuman terhadap kedisiplinan santri di pesantren Modern Daarul 'Uluum Lido, maka penulis terjun ke lapangan dan kemudian mengolah data yang diperoleh tersebut dengan teknik yang telah ditentukan, kemudian menyajikan data sesuai dengan masalah yang ingin disajikan.

Tabel 1 Kegiatan wawancara

\begin{tabular}{|c|c|c|c|c|c|}
\hline No & Nama & \multicolumn{2}{|l|}{ Status } & Waktu & Tempat \\
\hline 1 & Dewi Sulandari & \multicolumn{2}{|c|}{$\begin{array}{l}\text { Kepala Pengasuhan } \\
\text { (ri ayah) Putri }\end{array}$} & $\begin{array}{l}\text { Tanggal 24, } 25 \text { Oktober } \\
2017, \text { jam } 20.30 \text { wib. }\end{array}$ & $\begin{array}{l}\text { Kantor riayah } \\
\text { putri }\end{array}$ \\
\hline 2 & Arsy Syakila & \multicolumn{2}{|l|}{$\begin{array}{l}\text { Santri } \\
\text { Bahasa) }\end{array}$} & $\begin{array}{l}\text { Tanggal } 21 \text { Oktober } \\
2016 \text {, jam } 16.00 \text { wib }\end{array}$ & $\begin{array}{l}\text { Kantor } \\
\text { Pelayanan } \\
\text { Santri }\end{array}$ \\
\hline 3 & Hesti Septiani & \multicolumn{2}{|c|}{$\begin{array}{l}\text { Santri (Bagian } \\
\text { Keamanan) }\end{array}$} & $\begin{array}{l}\text { Tanggal } 22 \text { Oktober } \\
\text { 2016, jam } 16.00 \text { wib }\end{array}$ & $\begin{array}{l}\text { Kantor } \\
\text { Pelayanan } \\
\text { Santri }\end{array}$ \\
\hline 4 & $\begin{array}{l}\text { Adinda Yasmin } \\
\text { Ramadanti }\end{array}$ & $\begin{array}{ll}\text { Santri } & \text { kelas } \\
\left(a^{\prime} d h o\right) & \end{array}$ & $4 \mathrm{C}$ & $\begin{array}{l}\text { Tanggal } 22 \text { Oktober } \\
\text { 2016, jam } 17.00 \text { wib }\end{array}$ & Di Teras Masjid \\
\hline 5 & Intan Fauziah & $\begin{array}{ll}\text { Santri } & \text { kelas } \\
\left(a^{\prime} d h o\right) & \end{array}$ & $4 B$ & $\begin{array}{l}\text { Tanggal } 23 \text { Oktober } \\
2016 \text {, jam } 17.00 \text { wib }\end{array}$ & Di Teras Masjid \\
\hline
\end{tabular}

\section{Pelaksanaan Hukuman Terhadap Kedisiplinan Santri}

\section{Disiplin Waktu}

Berdasarkan hasil wawancara yang dilakukan dengan para pengurus Pesantren Modern Daarul 'Uluum Lido yaitu Arsy Syakila (AS) selaku pengurus bagian bahasa dan Hesti Septiani (HS) selaku pengurus bagian keamanan, maka diperoleh berbagai pernyataan yang terkait dengan efektivitas hukuman terhadap kedisiplinan santri. Para pengurus ini mempunyai berbagai pendapat yang berbeda dalam tiga disiplin terkait yaitu disiplin waktu, disiplin belajar dan disiplin tingkah laku dan juga dalam satu elemen hasil temuan baru yaitu pengendalian diri yang merupakan bagian dari disiplin tingkah laku. Dari segi disiplin waktu sebagai pengurus mereka sama-sama sering tidak mengambil jatah makan pada waktunya yaitu pada jam 6 pagi, tetapi mereka sering mengambil jatah makan lewat temmannya sesama pengurus minta tolong diambilkan. AS menjelaskan bahwa penyebab dia tidak sempat untuk mengambil jatah makan pada waktunya adalah karena padatnya kegiatan di pagi hari khususnya pada hari senin, dia menerangkan bahwa pada hari tersebut santri di wajibkan untuk mengikuti upacara bendera, biasanya menurut AS, setiap upacara pasti memakan waktu yang lama yang membuatnya tidak sempat untuk mengambil jatah makan pada waktunya dan solusinya adalah meminta teman sekamarnya untuk mengambilkan jatah makanya. 
Lain halnya dengan Hesti Septiani, HS menerangkan bahwasanya tidak sempat untuk mengambil jatah makan pada waktunya adalah karena biasanya persiapan HS untuk berangkat ke kelas yang memakan waktu yang lama, yang membuatnya tidak sempat untuk mengambil jatah makan pada waktunya, diantaranya adalah waktu mandi dan menyiapkan buku yang akan di bawa ke kelas. Bahkan untuk hal mandi sebenarnya kadang-kadang dia tidak mengantri, HS menerangkan bahwasanya dia sering tidak mengantri mandi jika dia terburu-buru untuk berangkat ke masjid karena dia ingin berangkat ke masjid lebih awal, itupun apabila yang sedang mandi adalah temannya sesama kelas lima.

Sementara itu, dalam hal disiplin waktu yang berkaitan dengan berangkat ke kelas mereka berdua sama-sama pernah terlambat berangkat ke kelas, alasan yang mereka tuturkan pun hampir senada, HS menerangkan bahwasanya keterlambatannya berangkat ke kelas disebabkan karena tanggung jawabnya sebagai bagian keamanan, tanggung jawabnya adalah mengawasi santri di setiap rayon untuk tidak tidur lagi setelah shalat subuh dan dan melakukan pengontrolan atau pengecekan ke setiap ruangan dan kamar mandi dan selanjutnya dia harus bersiap-siap berangkat ke kelas, hal ini yang menyita waktunya untuk bersiap berangkat ke kelas. AS pun menerangkan bahwasanya keterlambatannya berangkat ke kelas adalah karena tanggung jawabnya sebagai pengurus bagian bahasa yang mengharuskannya mengawasi disiplin bahasa para santri sebelum akhirnya AS bersiap untuk berangkat ke kelas, dan dia menyebutkan bahwa sebenarnya pengurus di berikan dispensasi waktu 5 menit dari waktu yang sudah ditentukan untuk masuk ke kelas yaitu jam 07.00 WIB. Konsekuensi dari pelanggaran adalah hukuman, begitu menurut mereka, ketika mereka terlambat untuk masuk kelas hukumannya adalah dijewer atau dijemur selama satu jam pelajaran, dan mereka mengaku jera dengan hukuman yang diberikan.

Kedua responden yang merupakan pengurus ini pun sama-sama mengikuti salah satu ekstrakurikurer yang di laksanakan di dalam lingkungan pondok, HS mengikuti ekskul karate, dia mengatakan bahwasanya ketertarikannya pada karate memang sudah ada bahkan sebelum dia masuk Pesantren. Sedangkan AS mengikuti ekskul JMQ (Jam'iyyatul Qurro'), yaitu salah satu ekskul unggulan di Pesantren Modern Daarul 'Uluum Lido yang mengajarkan kepada santrinya untuk lebih fokus lagi dalam mempelajari al-Qur'an, Walaupun mereka berdua adalah pengurus tetapi ada yang mengawasi disiplin ibadah mereka yaitu ustadzah bagian peribadatan pusat, lebih lanjut HS menuturkan bahwasanya ada hukuman bagi pengurus yang terlambat untuk berangkat shalat berjamaah yaitu berdiri dibelakang/dijemur, kanis (OPSIH) mesjid dan lingkuangan sekitar mesjid,

Kedua responden lainnya yaitu Adinda Yasmin Ramadanti (AY) kelas 4C dan Intan Fauziah (IF) kelas 4B yang merupakan perwakilan dari salah satu a'dho (anggota) santri Pesantren Modern Daarul 'Uluum Lido, mempunyai pengalaman yang berbeda yang berkaitan dengan disiplin waktu, dari hasil wawancara penulis dengan AY dia menyebutkan bahwa dia selalu tepat waktu untuk mengambil jatah makan di pagi hari, dia menyebutkan bahwa penyebabnya adalah karena uang jajan yang minim yang dia terima per-bulan dari orangtuanya yang menyebabkannya jarang membeli makanan di kantin,

Lain halnya dengan IF, dia menerangkan bahwa dia jarang mengambil jatah makan 
pada pagi hari, disamping kadang dari lauknya yang dia tidak suka di dapur, juga menurutnya kegiatan di pagi harinya yang membuatnya tidak sempat untuk mengambil jatah makan dipagi hari. Menurutnya dia memang sering tidak makan pagi karena dia tidak suka dengan lauk pada pagi hari, terlebih lagi pada hari senin upacara bendera yang memakan waktu lama sampai para santri banyak yang tidak bisa mengambil jatah makan pada waktunya.

Persamaan dari kedua responden ini adalah sama-sama mengikuti salah satu ekskul yang diadakan pondok, AY mengatakan bahwa dia mengikuti ekskul marawis yang sudah menjadi hobinya sebelum masuk Pesantren, sedangkan IF mengatakan bahwasanya dia mengikuti ekskul pramuka, dan mereka berdua menerangkan kadang-kadang karena mengikuti ekskul tersebut mereka sering terlambat untuk berangkat shalat berjamaah khususnya shalat maghrib, karena biasanya untuk ekskul disediakan waktu setelah shalat ashar sampai jaros (bel) terkadang kegiatan suka melebihi jam yang sudah ditentukan terkadang maghrib baru selesai biasanya pramuka. Berkaitan dengan disiplin waktu masuk kelas IF menuturkan bahwasanya dia belum pernah sama sekali terlambat untuk berangkat ke kelas. Karena menurutnya dia akan rugi jika dia terlambat masuk kelas, pelajaran di Pesantren sangat banyak dibandingkan dengan pelajaran di sekolah luar, oleh karena itu seorang santri biasanya akan terlambat untuk bisa mengikuti pelajaran selanjutnya apabila ia tidak masuk pada pertemuan sebelumnya. Banyak hal yang menjadi alasan terlambatnya santri ketika masuk kelas, AY mengungkapkan pernyataan yang berbeda yaitu penyebab keterlambatannya masuk kelas adalah karena biasanya santri ini tidur kembali setelah selesai shalat subuh dan melaksanakan kegiatan setelah shalat subuh seperti belajar muhadatsah (penyampaian kosa kata).

Santri ini juga mengungkapkan bahwasanya setiap dari pelanggaran pasti ada hukumannya, dalam hal ini yaitu berhubungan dengan bagian pengajaran. Hukumannya bagi yang pertama kali terlambat adalah piket, yaitu membersihkan kelas dan di jemur.

\section{Disiplin Belajar}

Dalam hal disiplin belajar semua santri yang menjadi responden baik dari perwakilan mudabbir (pengurus) maupun perwakilan a'dho (anggota) mempunyai banyak pernyataan yang senada, dalam hal ini penulis mendahulukan penyajian data kedua responden dari perwakilan pengurus, yaitu sebagai berikut: Kedua reponden ini mempunyai persamaan yaitu kadangkadang mengantuk di kelas, mereka menyebutkan bahwa penyebab rasa kantuk yang meraka rasakan adalah karena padatnya kegiatan yang ada di pesantren, dari bangun tidur sampai tidur kembali ditambah tanggung jawab mereka sebagai pengurus yang harus mengatur kedisiplininan santri dalam berbagai hal, dan kurangnya istirahat adalah penyebab utamanya. Dalam hal ini mereka sependapat untuk membawa makanan ke kelas walaupun mereka tahu dan mengerti disiplin kelas yang melarang mereka untuk membawa makanan ke dalam kelas. Mereka menyebutkan bahwa makanan yang mereka bawa ke kelas adalah sebagai solusi untuk menghilangkan rasa kantuk yang kadang mereka rasakan dalam kelas. Bahkan HS menuturkan bahwasanya dia pernah dihukum karena ketahuan sedang makan permen saat guru sedang menerangkan pelajaran, dan HS diberi hukuman oleh guru yang bersangkutan yaitu untuk membawa permen untuk diberikan kepada seluruh 
teman sekelasnya. Bahkan karena seringnya dia mengantuk sampai-sampai dia dijuluki abu naum (tukang tidur) oleh temantemannya.

Selanjutnya HS mengaku walaupun sudah diberi hukuman seperti itu dia masih tetap mengulangi perbuatannya yaitu membawa makanan ke kelas, karena menurutnya itu adalah solusi untuk menghilangkan rasa kantuknya di kelas,

Ketika waktu senggang saat pergantian pelajaran mereka berdua mengaku menggunakannya sekedar untuk menghilangkan rasa kantuk yang mereka rasakan saat pembelajaran, HS menerangkan bahwa biasanya dia pergi ke kamar mandi untuk sekedar cuci muka untuk menghilangkan kantuknya, lain halnya dengan AS yang mengaku justru dia malah memilih untuk tidur sebentar untuk menghilangkan rasa kantuk yang dia rasakan.

Dalam hal berbahasa maka pesantren modern daarul 'uluum lido mewajibkan santrinya untuk menggunakan bahasa Arab dan bahasa Inggris kedua responden ini mengaku bahwa mereka pun tetap harus menaati disiplin bahasa walaupun mereka sudah menjadi pengurus, terlebih lagi AS yang merupakan pengurus bagian bahasa, AS menerangkan bahwasanya berat sekali untuk menjadi bagian bahasa, karena bahasa merupakan taajul ma'had (mahkota pondok) yang harus dijaga dengan baik dan sungguhsungguh. Walaupun sudah menjadi pengurus tapi tetap ada yang mengawasi disiplin bahasa yaitu bagian pusat bahasa yang merupakan pusat pengembangan bahasa (P2B) di Pesantren Modern Daarul 'Uluum Lido. Walaupun pengurus bagian bahasa sebenarnya tidak akan masuk persidangan bagian P2B, tetapi menurut AS pernah ada bagian bahasa yang masuk bagian $\mathrm{P} 2 \mathrm{~B}$ terlebih lagi yang masuk adalah ketua bagian itu sendiri.

Lain halnya dengan HS yang mengaku bahwa dia pernah masuk P2B karena sedikit berbahasa Indonesia, itu pun menurutnya, karena solidaritasnya kepada teman, dia menerangkan bahwa ketika kelas 5 mendapatkan kertas jasus P2B maka temanteman kelas 5 yang lain harus bersedia untuk di tulis namanya di kertas jasus tersebut jika dia belum pernah masuk persidangan P2B, ataupun baru sekali masuk persidangan. Dalam kebanyakan disiplin di Pesantren Modern Daarul 'Uluum Lido menggunakan sistem jasus, yaitu menggunakan mata-mata untuk mencari pelanggar disiplin, dan menuliskan nama si-pelanggar tersebut di kertas jasus untuk kemudian diserahkan kepada pengurus terkait.

Belajar malam yang dimulai ba'da shalat isya yaitu sekitar jam 20.00 WIB sampai jam 21.30 WIB menurut salah satu responden yang merupakan bagian keamanan ini justru tidak bisa dia gunakan dengan baik, karena tanggung jawab seorang pengurus bagian keamanan adalah untuk selalu mengawasi disiplin santri yang berhubungan dengan bagian keamanan dan membantu bagian pengajaran untuk mendisiplinkan belajar malam santri.

Berkaitan dengan disiplin belajar anggota pun sebenarnya tidak jauh berbeda, kedua responden ini menerangkan mereka sering mengantuk di kelas, penyebabnya pun berbeda, AY mengatakan bahwa penyebab dari kantuknya adalah karena padatnya kegiatan pondok yang membuatnya lelah ketika di kelas, dan juga karena malamnya dia kurang tidur. Berbeda dengan AY, IF menerangkan bahwa penyebabnya adalah metode ceramah yang dipakai guru dalam mengajar yang membuatnya jenuh dan mengantuk. Bahkan IF mengatakan dia sering membawa makanan ke dalam kelas, 
walaupun dia tahu dan mengerti disiplin kelas yang melarangnya untuk tidak membawa makanan ke dalam kelas. Untuk menghilangkan kantuknya kadang IF makan permen, atau cuci muka ke kamar mandi, bahkan bercanda dengan temannya untuk mengisi waktu senggang saat pergantian pelajaran.

Dalam kaitannya dengan disiplin belajar berbahasa wajib yaitu bahasa Arab dan bahasa Inggris, kedua responden ini mempunyai cerita yang menarik untuk diteliti. Yang pertama adalah dari IF, AY mengaku bahwa dia kesulitan untuk berbahasa wajib karena dia kurang lancar untuk berbahasa wajib, bahkan dia mengaku kadang-kadang dia tidak berbahasa wajib jika tidak ada pengurus, itu pun jika teman yang dia ajak ngobrol adalah teman dekatnya yang bukan jasus, dia pun menerangkan kadang-kadang ada juga teman dekatnya yang tetap saja menuliskan namanya di kertas jasus. Santri ini mengaku tahun ini dia sudah tiga kali masuk persidangan bagian bahasa, dan hukuman yang dia terima ketika masuk persidangan bagian bahasa untuk yang ketiga kalinya adalah menulis kosakata (kosakata) sebanyak 60 dan dihapalkan kemudian dibuat di satu kalimat, ditambah lagi di jemur dan pake kerudung warnawarni. Masih berhubungan dengan pelanggaran disiplin bahasa, kedua responden ini pun mengatakan sering melihat contoh tidak baik dari kakak kelas, AY mengatakan dia sering melihat kakak kelas yang seenaknya berbahasa indonesia, begitu juga dengan IF, Dia menerangkan bahwa kakak kelas yang dia kenal banyak yang mencontohkan perlakuan buruk yang tidak layak mereka contohkan di depan anggota mereka, selanjutnya IF menerangkan bahwa mungkin mereka berani untuk berbuat seperti itu karena mereka sudah menjadi pengurus.

\section{Disiplin Bertingkah Laku}

Dalam penyajian datanya, disiplin bertingkah laku terbagi menjadi dua bagian pembahasan, yaitu:

1. Hubungan dengan orang lain

Dalam hal yang berhubungan dengan disiplin tingkah laku sebagai seorang pengurus HS dan AS banyak dikenal oleh adik kelas, mereka menerangkan bahwa mereka banyak dikenal oleh adik kelas karena mereka merupakan pengurus yang menggerakkan disiplin yang berhadapan dengan adik kelas ataupun anggota setiap hari. HS mengatakan, ada adik kelas yang akrab dengan dia, tapi tidak sedikit juga adik kelas yang membenci dia, hal ini disebabkan karena HS adalah pengurus bagian keamanan yang mengharuskannnya untuk selalu menjaga wibawa dan bersikap tegas kepada anggota, khususnya kepada anggota yang melanggar, dia tidak pilih kasih dalam memberikan hukuman. Lain halnya dengan AS, dia menerangkan bahwa banyak sekali adik kelas yang dekat dengan dia, khususnya adik kelas yang di JMQ, banyak adik kelas yang sering datang kepada dia untuk menanyakan suatu pelajaran. Hubungan kedua responden ini dengan sesama pengurus pun cukup baik, mereka mengenal semua pengurus, HS mengatakan bahwa dia mengenal baik semua pengurus putri tapi tidak mengenal keseluruhan dari pengurus putra, begitupun dengan AS, dia mengenal semua pengurus yang putri dan tidak dengan pengurus putra. Hubungan kedua responden ini dengan guru lainnya sama-sama kurang dekat/baik, ini terlihat dari kedekatan mereka yang hanya kepada wali kelasnya saja, dan memang sudah menjadi tanggung jawab seorang wali kelas untuk bisa menjadi bapak bagi anak-anak kelasnya, dan kedua responden ini sama-sama tidak mengenal semua guru-guru yang mengajar di Pesantren Modern Daarul 'Uluum Lido, dari 
hasil pernyataan wawancara mereka mengaku sama-sama hanya mengenal guru yang pernah mengajar mereka saja.

Dalam hal yang berhubungan dengan disiplin tingkah laku responden yang merupakan a'dho (anggota) AY dan IF mengatakan, mereka sering mengadakan kegiatan belajar kelompok yang merupakan inisiatif dari mereka sendiri dan teman teman, ini menunjukkan bahwasanya mereka mempunyai pergaulan yang positif dengan teman-teman mereka, dan mereka pun mempunyai persamaan dalam pernyataan mereka yang berkaitan dengan hubungan baik mereka dengan teman-teman mereka, AY menerangkan bahwasanya dia hanya mengenal baik dengan semua temantemannya yang putri saja, begitupun sebaliknya dengan IF, dia mengatakan bahwa dia hanya hafal dengan temantemannya yang putri saja tapi tidak mengenal semua teman-teman putra yang se-angkatan dengannya.

Hubungan mereka dengan pengurus pun bisa dikatakan cukup baik, ini terlihat dari pernyataan AY mengatakan dia dekat sekali dengan salah satu pengurus bagian ibadah, dan IF pun demikian, IF mengatakan dia dekat dengan salah satu pengurus, yaitu tepatnya pengurus bagian bahasa, dia sering sekali menanyakan pelajaran yang dia anggap sulit kepada pengurus tersebut, ini menunjukkan terbangunnya sebuah hubungan yang positif diantara mereka antara anggota dengan pengurus. Sedangkan berkaitan dengan hubungan mereka dengan adik kelas, mereka mempunyai pernyataan yang berbeda satu sama lain. AY mengatakan dia banyak mengenal adik kelas karena menurutnya dia adalah orang yang gampang bergaul dengan orang lain, lain halnya dengan IF, dia menerangkan bahwa dia kurang bisa bergaul dengan adik kelas. Yang menjadi persamaan dari kedua responden ini selanjutnya adalah sama-sama tidak mengenal semua guru di Pesantren Modern Daarul 'Uluum Lido, tapi mereka mengatakan apabila bertemu dengan guru baik dikenal maupun tidak dikenal, mereka hanya memberi salam saja.

\section{Pengendalian diri}

Pengendalian diri disini merupakan satu elemen temuan baru yang ditemukan penulis dari hasil pengolahan data melalui wawancara mendalam, observasi dan telaah dokumen. Pengendalian diri adalah temuan baru yang dianggap perlu untuk di teliti lebih lanjut yang merupakan bagian dari disiplin bertingkah laku, khususnya dalam hal kaitannya dengan pembahasan penelitian ini yaitu efektivitas hukuman untuk meningkatkan santri.

\section{Pembahasan}

Pembahasan yang pertama adalah penyajian data hasil wawancara penulis dengan pengurus, yaitu dalam hal pengendalian diri, banyak pernyataan dari HS yang berhubungan dengan elemen ini, itu disebabkan karena memang HS adalah salah satu orang yang menggerakkan disiplin keamanan, HS menerangkan bahwasanya masih banyak kesulitan yang dia hadapi sebagai pengurus bagian keamanan, diantaranya adalah dia masih menemukan santri yang banyak melanggar yang dia temukan diluar persidangan, walaupun menurutnya pelanggaran yang dilakukan adalah pelanggaran kecil, seperti makan dan minum berdiri atau tidur tidak pada waktunya. Bahkan HS pernah menyidang dan menjemur mengenakan kerudung warna-warni selama lima hari santri yang ketahuan mencuri di kamar, menurut HS itu adalah hukuman terberat yang akan diterima santri apabila mencuri. Lebih dari itu kabur dari pondok misalnya, atau mengintimidasi santri, maka santri tersebut 
akan langsung diserahkan kepada bagian pengasuhan pusat (ri'ayah).

Disamping itu tutur HS, banyak dari teman-temannya yang tidak bisa mengendalikan diri yang melanggar disiplin tetapi tidak pernah ketahuan oleh ri'ayah, karena menurut HS mereka sesama kelas 5 tidak akan melaporkan temannya yang melanggar, santri ini tidak bisa mengatakan apakah ini bentuk dari solidaritasnya kepada sesama teman atau bahkan tindakan salah yang membiarkan pelanggaran terjadi. Banyak sekali teman yang melanggar, bahkan menurut HS ada temannya yang sampai dikeluarkan dari pondok karena ketahuan sering kabur dari pondok.

Lain halnya dengan AS, dalam elemen ini yaitu yang berkaitan dengan pengendalian diri hanya sedikit pernyataan AS yang berhubungan, diantaranya adalah pernyataan AS yang menerangkan bahwasanya AS kadang-kadang pada jam wajib belajar malam yaitu setelah shalat isya sampai jam 21.30 waktu setempat tidak belajar, AS malah lebih memilih untuk mengobrol dengan teman-temannya,

Pembahasan yang kedua adalah penyajian data hasil wawancara penulis dengan santri Daarul 'Uluum Lido yang merupakan a'dho (anggota), yaitu sebagai berikut:

Disiplin keamanan Pesantren Modern Daarul 'Uluum Lido yang lebih terkait dengan pengendalian diri santri, dirasakan ketat sekali oleh santri yang masih menjadi anggota, hal ini karena santri yang masih menjadi anggota pengawasan keamanannya berasal dari dua pihak, yaitu pengurus bagian keamanan itu sendiri dan bagian pengasuhan pusat (ri'ayah), dari wawancara penulis dengan responden yang terpilih mereka menyatakan bahwa mereka pernah melanggar disiplin keamanan, seperti tidur tidak pada waktunya ataupun makan dan minum dengan berdiri, padahal hal ini dilarang untuk dilakukan di lingkungan Pesantren, tetapi mereka mengaku tidak pernah melanggar pelanggaran yang berat, seperti pacaran, mencuri, berkelahi ataupun kabur dari pondok. Dan mereka menerangkan bahwa sebenarnya mereka justru lebih sering menemukan banyak contoh yang tidak baik dari kakak kelas yang tidak bisa mengendalikan dirinya dengan baik dan secara tidak langsung telah mencontohkan prilaku buruk kepada santri lain, IF mengatakan bahwa dia sering menemukan kakak kelas yang makan dan minum dengan berdiri, bahkan dia menambahkan bahwa dia pernah menemukan kakak kelas yang berkata dengan teriak-teriak.

\section{Interpretasi Hasil Penelitian tentang Efektivitas Hukuman untuk Meningkatkan Disiplin Santri Putri}

Pada penelitian ini diperoleh fakta bahwa efektivitas hukuman terhadap kedisiplinan santri bervariasi diantara para santri, faktor kelas pun turut serta dalam mempengaruhi efektivitas hukuman, faktanya adalah santri yang sudah kelas 5 dan kelas 6 justru lebih banyak melakukan pelanggaranpelanggaran berat seperti terlambat bangun pagi, kabur dan terlambat masuk kelas, pacaran. faktor kelas memang berperan besar dalam pelanggaran santri, karena seorang pengurus mempunyai waktu luang yang lebih banyak dibandingkan dengan anggota yang berpotensi untuk melanggar suatu disiplin. Hal ini pun senada dengan penuturan dari salah satu responden yang merupakan pengurus yang mengatakan bahwa disiplin bagi seorang pengurus ataupun kelas tinggi pada umumnya kembali kepada dirinya masing-masing lagi, karena banyaknya potensi untuk melakukan pelanggaran jadi mereka harus mempunyai dhomir (hati kecil) yang baik untuk bisa 
menaati disiplin walaupun tidak ada bagian ri'ayah yang melihat.

\section{Efektivitas Disiplin Waktu}

Dari pernyataan hasil wawancara mendalam kepada semua responden yang berhubungan dengan disiplin waktu, semua responden mengatakan bahwa mereka semua pernah terlambat berangkat ke kelas, hal yang menyebabkannya pun berbeda dari semua responden, kebanyakan dari mereka mengatakan bahwa yang menyebabkan keterlambatan mereka adalah karena padatnya kegiatan pada pagi hari setelah shalat subuh, para pengurus yang sibuk mengawasi disiplin anggota dan anggota yang diwajibkan untuk selalu tepat waktu dalam segala hal khususnya untuk berangkat ke kelas, hukuman yang diberikan dikelas oleh guru yang bersangkutan cukup efektif dalam membuat santri jera untuk tidak melakukan kesalahan yang sama, sebagaimana yang telah diungkapkan oleh salah satu responden yang merupakan salah satu pengurus yang mengatakan bahwa hukuman berupa dijemur/jeweran cukup memebuatnya jera untuk tidak akan terlambat lagi masuk kelas.

Berkaitan dengan disiplin waktu mandi, terlihat bahwa yang menjadi permasalahan bagi santri adalah santri putri yang diharuskan untuk mengantri mandi di luar kamar, Hal ini menyebabkan banyaknya pelanggaran yang terjadi ketika mandi, salah satunya adalah santri yang mandi lebih dari seorang dalam satu kamar mandi, sebenarnya hal itu merupakan pelanggaran disiplin tetapi tetap saja masih banyak santri yang melakukannya, bahkan mandi bersama sudah menjadi sebuah kebiasaan bagi sebagian santri. Dalam kaitannya dengan waktu makan santri, semua responden mengatakan sering tidak sempat makan pagi karena padatnya kegiatan pada pagi hari, kecuali salah satu responden yang mengatakan bahwasanya dia selalu tepat waktu ketika akan mengambil jatah makan pada pagi hari karena dia tidak mempunyai uang jajan yang lebih untuk membeli makanan ke kantin seperti kebanyakan santri lainnya. faktor lauk-pauk yang disediakan di dapur pun mempengaruhi keinginan santri untuk makan di pagi hari bahkan santri lebih memilih untuk tidak makan karena lauknya yang kurang enak menurut dia. Hari senin yang merupakan hari upacara pun menjadi kendala bagi sebagian santri untuk bisa mengambil jatah makan pada waktunya, penyebabnya adalah dipercepatnya waktu masuk kelas santri 15 menit lebih awal dari sebelumnya.

Hal yang berkaitan dengan waktu shalat berjamaah kebanyakan responden tidak ada masalah dengan itu, hal ini menunjukkan bahwa disiplin shalat berjamaah santri sudah relatif bagus, dan menurut salah satu responden bahwa biasanya semua santri tepat datang ke masjid pada waktunya untuk melaksanakan shalat berjamaah walaupun kadang masih banyak yang masbuq, dan yang mendapatkan hukuman adalah santri yang telat untuk datang ke masjid, bukan yang masbuq, penyebabnya adalah karena wudhunya yang mengantri, untuk itulah pengurus bagian ibadah selalu mengawasi saat santri sedang berwudhu, dan akan menghitung santri yang sedang wudhu jika shalat akan segera dimulai. Hukuman yang diberikan kepada santri yang masih berwudhu setelah diberi hitungan oleh pengurus adalah di pukul tangannya, dan hukuman tersebut efektif dalam mendisiplinkan santri untuk bersegera dalam berwudhu.

Semua responden yang merupakan santri mengaku mengikuti salah satu ekstrakurikurer di pondok dan ternyata ada ekskul yang kadang membuat santri menjadi melanggar salah satu disiplin yang lain, 
untuk shalat maghrib berjamaah misalnya, keterlambatan yang disebabkan oleh ekskul untuk shalat maghrib berjamaah karena biasanya waktu latihan ekskul adalah setelah shalat ashar sampai jaros makan sore, dan terkadang santri melebihi waktu yang sudah ditentukan untuk ekskul. Hal tersebut tersebut memakan waktu yang lama lebih daripada waktu yang sudah ditentukan. Akibatnya santri telat untuk mandi dan makan sore, terlebih lagi untuk berangkat shalat maghrib berjamaah. Lebih lanjut lagi salah satu responden yang merupakan kepala BPPS putri yaitu Ustadzah Dewi Sulandari mengatakan bahwasanya faktor yang paling berpengaruh dalam mendisiplinkan waktu santri adalah yang berwenang dalam menegakkan disiplin tersebut, dalam hal ini yaitu pengurus yang bersangkutan,

Hal ini juga terlihat dari kebijakan dewan guru yang mempercayakan pengurus yang terkait untuk merumuskan sendiri hukuman apa yang akan mereka berikan kepada santri yang melanggar disiplin, dan mengkonsultasikannya dahulu kepada bagian pusat sebelum akhirnya diterapkan. Hal ini dimaksudkan agar tidak ada pengurus yang memberikan hukuman non-prosuderal kepada pelanggar disiplin.

\section{Efektivitas Disiplin Belajar}

Berkaitan dengan disiplin belajar semua responden mengatakan bahwasanya mereka pernah mengantuk di kelas saat pembelajaran sedang berlangsung, penyebabnya adalah karena padatnya kegiatan di pondok mulai dari bangun tidur sampai tidur kembali. Terlebih lagi karena metode pembelajaran yang dipakai oleh guru yang mengajar yang kurang bervariatif yang hanya memakai metode ceramah kadang membuat siswa jenuh dan mengantuk di kelas. Dan mereka semua mengaku pernah membawa makanan ke dalam kelas, gunanya adalah agar ketika mereka mengantuk mereka bisa menghilangkan kantuknya dengan makan, tetapi justru mereka akan dihukum apabila ketahuan makan saat belajar, sampai-sampai salah satu responden mengatakan bahwa dia pernah di hukum membawa permen untuk se-kelas karena ketahuan makan permen saat pembelajaran, tetapi hukuman itu tidak membuatnya jera dan dia masih saja membawa permen setelah itu.

Di Pesantren Modern Daarul 'Uluum Lido bahasa Arab dan bahasa Inggris merupakan salah satu keunggulan dari pesantren, bahkan sampai saat ini kemampuan berbahasa santri Daarul 'Uluum Lido bisa diacungkan jempol karena sering memenangkan lomba-lomba yang berhubungan dengan bahasa, seperti lomba pidato bahasa Arab misalnya, debating dengan bahasa Inggris, dsb. Bahasa Arab dan bahasa Inggris merupakan mahkota Pondok yang harus dijaga oleh setiap individu dari santri Daarul 'Uluum Lido. Salah satu responden mengatakan bahwa setelah dia menjadi pengurus bagian bahasa dia sudah tidak lagi masuk bagian bahasa pusat (P2B), hal ini sebenarnya menjadikan suatu perasaan iri dari teman-temannya yang lain selain pengurus bagian bahasa yang terkesan diistimewakan oleh $\mathrm{P} 2 \mathrm{~B}$, tetapi pengurus bagian bahasa pun akan tetap masuk persidangan bagian bahasa pusat apabila berbahasa dengan indonesia (gaul), sebagaimana kasus yang pernah terjadi, yaitu salah satu pengurus bagian bahasa tepatnya ketua bagian bahasa yang masuk persidangan bagian bahasa pusat (P2B) karena di laporkan oleh salah satu santri yang melihatnya berbicara batavia (gue, loe), ini merupakan bentuk perlawanan santri terhadap pengurus yang menggerakkan disiplin tapi justru mereka sendiri tidak menjalankannya. 
Semua responden mengaku selalu mengikuti muwajahah pada malam hari, muwajahah adalah belajar malam yang di adakan oleh wali kelas untuk menunjang pembejalaran santri dalam kelas yang membahas tentang pelajaran-pelajaran yang dianggap sulit oleh santri. Sebagian dari responden menerangkan bahwa mereka mengikuti muwajahah karena sebentar lagi akan menghadapi ujian yang memerlukan banyak persiapan pembelajaran, maka mereka harus giat belajar, sedangkan sebagian yang lain mengatakan bahwasanya mereka mengikuti muwajahah karena takut dihukum, karena akan ada sanksi bagi siapa saja yang tidak mengikuti muwajahah, hal ini menunjukkan bahwa hukuman yang diberikan bagi siapa yang tidak mengikuti muwajahah pada malam hari cukup efektif dalam mendisiplinkan santri untuk belajar. Walaupun pada awalnya santri merasa terpaksa untuk melakukannya. Kebijakan ri'ayah pun ikut andil dalam mendisiplinkan belajar santri, karena akan ada hukuman yang tegas bagi santri yang tidak mau belajar pada malam hari, lebih jelasnya ustadzah Dewi Sulandari.

Bahkan lebih lanjut lagi beliau menerangkan bahwa walaupun dia adalah kelas 5 dan 6 yang merupakan pengurus bagian dan nihai, tetap akan diberi hukuman yang setimpal dengan perbuatannya, untuk dijadikan pelajaran bagi santri lain, khususnya kepada pengurus bagian yang lain untuk tidak menganggap remeh disiplin walaupun sudah menjadi pengurus ataupun kakak kelas.

\section{Efektivitas Disiplin Bertingkah Laku}

Sebagaimana telah diterangkan di atas dalam penyajian data, dalam interpretasi datanya pun penulis membagi disiplin bertingkah laku menjadi dua bagian bahasan, yaitu hubungan dengan orang lain yang merupakan indikator dasar dari disiplin bertingkah laku, dan pengendalian diri yang merupakan temuan baru dari hasil pengolahan data. Interpretasi datanya adalah sebagai berikut.

1. Hubungan dengan orang lain

Berdasarkan dari hasil wawancara mendalam dengan para responden yang merupakan santri diketahui bahwasanya semuanya bergaul baik dengan teman seangkatan mereka, banyak dari temanteman yang mempunyai tabi'at yang kurang baik dengan terus-terusan melanggar berbagai macam disiplin walaupun hukuman sudah mereka dapatkan. Tetapi ada pula hubungan positif yang terjalin diantara teman, seperti yang dipaparkan responden yang menyatakan bahwa mereka sering mengadakan belajar kelompok bersama dengan teman-teman seangkatan. Mereka pun berhubungan baik dengan pengurus, hal ini ditunjukkan dari kedekatan mereka dengan salah satu pengurus bagian. AY mengatakan bahwa dia dekat dengan pengurus bagian ibadah, sedangkan IF mengatakan dia dekat dengan pengurus bagian bahasa. Kedekatan mereka membawa kepada hal yang positif yang ditunjukkan dengan kebersamaan mereka dalam belajar dan berangkat shalat berjamaah. Lain halnya dengan AY dan IF, HS dan AS yang merupakan pengurus bagian mengatakan bahwasanya banyak adik kelas yang dekat dengan mereka tetapi banyak juga yang membenci, khususnya HS, sebagaimana yang telah diterangkan oleh HS bahwasanya bagian keamanan merupakan bagian yang banyak dibenci oleh para anggota, ini disebabkan tanggung jawab seorang pengurus bagian keamanan yang mengharuskan bersikap tegas dan adil dalam menghukum santri.

Terkait hubungan santri dengan guru, santri terlihat kurang bisa bergaul dengan guru-guru di Pesantren Modern Daarul 
'Uluum Lido, ini terlihat pernyataan santri yang mengaku hanya mengenal guru-guru yang pernah mengajar mereka saja. Mereka hanya dekat dengan wali kelas mereka masing-masing, hal ini merupakan suatu kekurangan dalam berdisiplin tingkah laku, karena sudah seharusnya seorang murid untuk mengenal gurunya walaupun guru yang belum pernah mengajar sama sekali. Pancajiwa pondok dan motto pondok menjadi sorotan penulis dalam kaitannya dengan disiplin bertingkah laku, ukhuwah islamiyah khususnya, semua santri diharapkan bisa mengaplikasikan jiwa ukhuwah islamiyah dalam kehidupan sehariharinya, yaitu jiwa persaudaraan atas nama Islam yang mengedepankan nilai-nilai moral yang baik, saling tolong menolong dalam kebaikan, mengajak kepada yang ma'ruf dan mencegah kepada yang mungkar.

Ukhuwah islamiyah adalah salah satu Pancajiwa Pesantren Modern Daarul 'Uluum Lido. Pancajiwa adalah lima prinsip dasar yang harus tertanam dalam jiwa siapapun yang menjadi penghuni pondok, entah itu kiyai, guru ataupun santri. Maksud dari ukhuwah islamiyah adalah menjalin hubungan sesama manusia yang berasaskan kepada prinsip dari ajaran Islam yang damai dan toleran. Ukhuwah dalam Islam adalah nilai persaudaran dengan semangat tolong menolong yang tidak melihat batas-batas tertentu, seperti golongan, etnik bahkan agama atau keyakinan orang lain. Islam menyuruh umatnya untuk menghormati siapapun, bekerjasama dan bergaul tanpa memandang status sosial bahkan keyakinannya. Sudah sewajarnya ukhuwah islamiyah menjadi sorotan bagi beliau, karena hubungan seseorang dengan orang lain bisa mempengaruhi akhlak orang tersebut, oleh karena itu seorang santri harus memilih dalam bergaul.

2. Pengendalian diri
Para responden yang merupakan anggota mengatakan bahwa mereka sering melihat kakak kelas yang tidak bisa mengendalikan dirinya dengan baik, seperti makan dan minum berdiri, kemudian ditambahkan juga bahwa kadang ada kakak kelas yang berbicara dengan teriak-teriak, yang seharusnya tidak layak untuk dilakukan oleh kakak kelas yang seharusnya mencontohkan yang baik kepada adik kelasnya. Bahkan terkadang ada pengurus yang memarahi santri dengan kata-kata kotor yang tidak seharusnya keluar dari mulut seorang santri, apalagi hal tersebut bertentangan dengan teori pendidikan. Dan pada faktanya, hukuman yang diberikan oleh pengurus yang nakal yang memberikan hukuman nonprosuderal pun menjadi salah satu kasus yang ditemui penulis saat wawancara dan telaah dokumen, salah satu santri kelas 5 yang merupakan pengurus disidang oleh bagian keamanan pusat dan diberi peringatan keras karena ketahuan memberikan hukuman di luar dari kebijakan Pondok Pesantren. Hal ini tidak seharusnya dilakukan, karena akan menimbulkan perasaan benci anggota kepada pengurus, walaupun memang terbukti hukuman seperti itu akan sangat efektif dalam membuat santri jera.

Salah satu responden yang merupakan bagian keamanan pun menuturkan bahwa banyak kesulitan yang dia hadapi selaku bagian keamanan, diantaranya adalah santri yang tetap saja melanggar walaupun setelah diberi hukuman, tetapi biasanya hanya sekedar pelanggaran kecil seperti makan ataupun minum dengan berdiri dan tidur tidak pada waktunya. Dan santri akan jera untuk tidak melakukan pelanggaran berat lagi apabila telah dihukum, seperti yang dikatakannya bahwa dia pernah menyidang santri yang ketahuan pacaran. Hal ini terbukti tidak hanya efektif dalam 
mendisiplinkan si pelanggar disiplin, tetapi juga efektif untuk teman-temannya yang melihatnya telah dihukum untuk tidak mengikuti perbuatannya.

Sementara itu, jika pelanggarannya sangat berat seperti berkelahi dan keluar dari pondok tanpa izin (kabur) serta pelanggaran itu dilakukan berulang-ulang maka santri tersebut langsung diserahkan kepada ri'ayah untuk selanjutnya diberikan hukuman berat, yaitu dikeluarkan dari Pesantren, karena pengurus bagian dari santri tidak mempunyai hak untuk memberikan hukuman seperti itu. bahwa santri yang melakukan pelanggaran berat dan mendapatkan hukuman sampai dikeluarkan dari pondok merupakan santri kelas tinggi yaitu kelas lima dan enam. Hukuman yang diberikan kepada santri yang melanggar pada dasarnya merupakan suatu pendidikan yang harusnya menjadi pelajaran bukan hanya bagi pelanggar disiplin tapi juga santri yang belum melanggar agar mengurungkan niatnya untuk melanggar.

Hukuman yang diberikan kepada pelanggar disiplin sudah sewajarnya diterima, karena konsekuensi dari ketaatan adalah hadiah dan pelanggaran adalah hukuman, sedangkan tujuan dari hukuman itu sendiri merupakan penunjang untuk berjalannya sistem di suatu lembaga pendidikan,

Disamping itu, hukuman yang diberikan juga harus bertahap dan klasikal. Yang berarti bahwa hukuman harus disesuaikan dengan seberapa berat tingkat pelanggaran yang dilakukan, dan berasal dari kelas berapa orang yang melakukan pelanggaran tersebut pada Tabel 2.

Tabel 2 Hasil penelitian tentang efektivitas hukuman untuk meningkatkan disiplin santri putri

\begin{tabular}{|c|c|c|c|}
\hline Nama & Pelanggaran & Hukuman & $\begin{array}{c}\text { Perilaku } \\
\text { Santri Pasca } \\
\text { Hukuman }\end{array}$ \\
\hline \multirow[t]{5}{*}{ Arsy Syakila } & $\begin{array}{l}\text { Tidur larut } \\
\text { malam }\end{array}$ & $\begin{array}{l}\text { Ditegur dan Dijemur pada jam istirahat } \\
\text { kedua }\end{array}$ & Jera \\
\hline & $\begin{array}{l}\text { Terlambat } \\
\text { shalat } \\
\text { berjamaah }\end{array}$ & $\begin{array}{l}\text { Dijewer, dijemur, lari keliling lapangan, } \\
\text { mengenakan kerudung dua warna } \\
\text { (oranye-kuning) selama } 3 \text { hari, } \\
\text { Kanis/OPSIH }\end{array}$ & Jera \\
\hline & $\begin{array}{l}\text { Terlambat } \\
\text { masuk kelas }\end{array}$ & Dijewer dan dijemur 1 jam pelajaran & Jera \\
\hline & $\begin{array}{l}\text { Mengantuk di } \\
\text { kelas }\end{array}$ & Dibangunkan, ditegur dan dikagetkan & Tidak jera \\
\hline & $\begin{array}{l}\text { Membawa } \\
\text { makanan ke } \\
\text { kelas }\end{array}$ & $\begin{array}{l}\text { Berdiri di depan kelas/luar kelas dengan } \\
\text { dikalungkan tulisan kesalahannya dan } \\
\text { membawa permen untuk semua teman } \\
\text { satu kelas }\end{array}$ & Jera \\
\hline $\begin{array}{l}\text { Hesti } \\
\text { Septiani }\end{array}$ & $\begin{array}{l}\text { Berbicara } \\
\text { dengan bahasa } \\
\text { indonesia }\end{array}$ & $\begin{array}{l}\text { Mengenakan kerudung dua warna (hijau- } \\
\text { kuning) selama tiga hari, Di jemur dengan } \\
\text { mengalungkan papan nama bertuliskan } \\
\text { jenis pelanggarannya selama 15-20 menit, }\end{array}$ & Jera \\
\hline
\end{tabular}




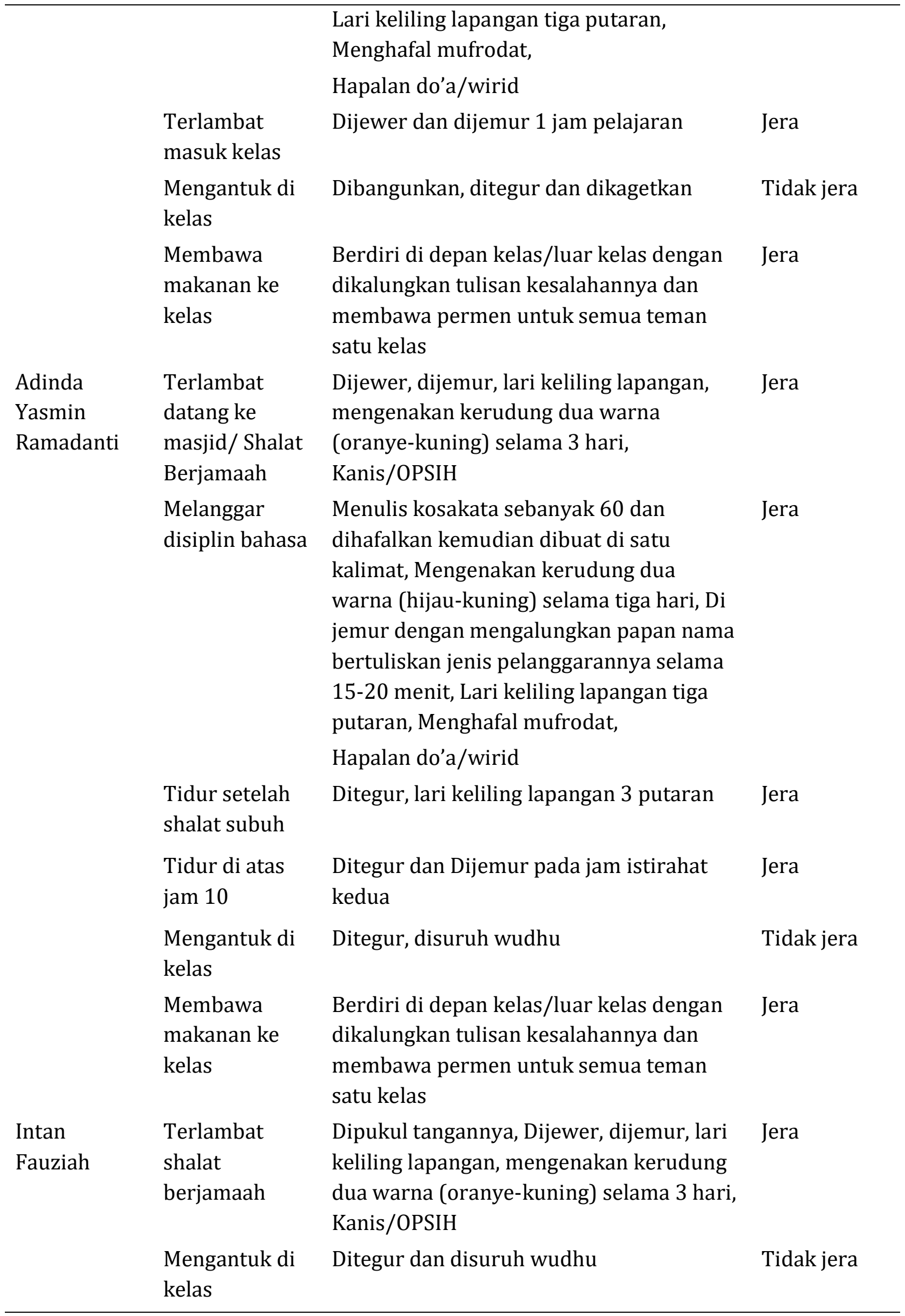




$\begin{array}{lll}\begin{array}{l}\text { Satu kali } \\ \text { Melanggar } \\ \text { disiplin bahasa }\end{array} & \begin{array}{l}\text { Menulis 200 kosakata tanpa } \\ \text { menghafalnya }\end{array} & \text { Jera } \\ \text { Membawa } & \text { Berdiri di depan kelas/luar kelas dengan } & \text { Jera } \\ \text { makanan ke } & \text { dikalungkan tulisan kesalahannya dan } & \\ \text { kelas } & \text { membawa permen untuk semua teman } & \\ & \text { satu kelas } & \end{array}$

\section{KESIMPULAN DAN IMPLIKASI}

\section{Kesimpulan}

Disiplin di Pesantren Modern Daarul 'Uluum Lido dirumuskan sedemikian rupa agar santri terbiasa berdisiplin dalam kehidupan sehari-harinya. Berdisiplin dalam hubungannya dengan orang lain, yaitu: dalam keluarga, masyarakat dan negara. Dan terlebih lagi yaitu berdisiplin diri dalam berhubungan dengan Tuhannya. Pemberian hukuman kepada santri yang melanggar disiplin di Pesantren Modern Daarul 'Uluum Lido mengedepankan kepada unsur edukatif tanpa kekerasan fisik, hukuman yang diberikan bertahap dan jenis hukumannya pun berbeda tergantung dari tingkat pelanggarannya dan santri yang melanggarnya. Hukuman yang diberikan kepada pelanggar disiplin diharapkan agar santri merasa jera untuk tidak mengulangi kesalahan untuk yang kedua kalinya.

Balasan dari ketaatan adalah hadiah dan pujian, begitupun sebaliknya yaitu konsekuensi dari pelanggaran adalah hukuman. Hukuman yang diberikan kepada pelanggar disiplin di Pesantren Modern Daarul 'Uluum Lido terbukti efektif dalam mendisiplinkan santri agar tidak mengulangi kesalahannya untuk yang kedua kalinya. Lebih lanjut lagi hukuman tersebut dirasakan pula efeknya pada santri yang akan melakukan pelanggaran agar mengurungkan niatnya untuk melakukan pelanggaran disiplin.

\section{Implikasi}

a. Untuk dewan guru yang termasuk ke dalam penggerak disiplin pusat dari semua bagian, agar meninjau ulang kebijakan-kebijakan yang telah diberlakukan kepada santri untuk ditingkatkan kembali. Dengan cara menjaga kebijakan-kebijakan lama yang masih terbukti efektif dalam mendisiplinkan santri dan merumuskan kebijakan-kebijakan baru yang lebih efektif dalam mendisiplinkan santri Pesantren Modern Daarul ‘Uluum Lido.

b. Pengasuh santri putri untuk lebih aktif lagi dalam mengurus dan mendisiplinkan santri putri, namun tetap menjadi sosok yang tegas tetapi tetap disayangi para santri.

c. Untuk santri yang merupakan pengurus bagian

(mudabbir/mudabbirah) Pesantren Modern Daarul 'Uluum Lido, agar selalu sabar dalam mengurusi dan menggerakkan disiplin santri yang masih menjadi anggota untuk tidak memberikan hukuman di luar dari kebijakan Pesantren, karena pemberian hukuman non-prosuderal yang mengarah kepada kekerasan fisik akan menimbulkan perasaan benci dan keterpaksaan dalam menjalankan disiplin. 
d. Untuk semua santri baik itu pengurus maupun anggota, agar senantiasa ikhlas dalam menjalankan disiplin yang diberlakukan di Pesantren, karena setiap disiplin yang diberlakukan oleh Pesantren pasti ada manfaatnya untuk diri sendiri yang akan dirasakan nanti setelah menjadi alumni, yaitu akan bisa berdisiplin dalam kehidupan sehari-hari walaupun tidak ada yang mengawasi. Dan juga setiap santri agar memahami bahwa di setiap lembaga pendidikan pasti terdapat disiplin yang menjadi rambu-rambu dalam menciptakan suatu sistem pendidikan yang tertata rapi.

\section{DAFTAR PUSTAKA}

Binti M. 2010. Sosiologi pendidikan. Cetakan Kesatu. Ar-Ruzz Media, Yogyakarta.

Burhanuddin H dan N Wahyuni. 2015. Teori belajar \& pembelajaran. Cetakan kedua. Ar-Ruzz Media, Yogyakarta.
Gaza M. 2012. Bijak menghukum siswa: pedoman pendidikan tanpa kekerasan. Cetakan Kesatu. Ar-Ruzz Media, Yogyakarta.

Moleong LJ. 2016. Metodologi penelitian kualitatif. Cetakan Kesatu. Remaja Rosdakarya, Bandung.

Muasaroh. 2010. Pengertian efektivitas. Diunduh pada 5 Maret 2016 dari http://literaturbook.com.

Siagaan P. 2001. Manajemen sumber daya manusia. Cetakan kedua. Bumi Aksara, Yogyakarta.

Sugiyono H. 2016. Metode kualitatif dan kuantitatif. Cetakan ke-23. Alfabeta, Bandung.

Supardi dan Margono. 2014. Metodologi penelitian pendidikan. Cetakan Kesatu. Rineka Cipta, Bandung.

Surya M. 2003. Psikologi pembelajaran dan pengajaran. Cetakan Kesatu. Rosda Karya, Bandung. 